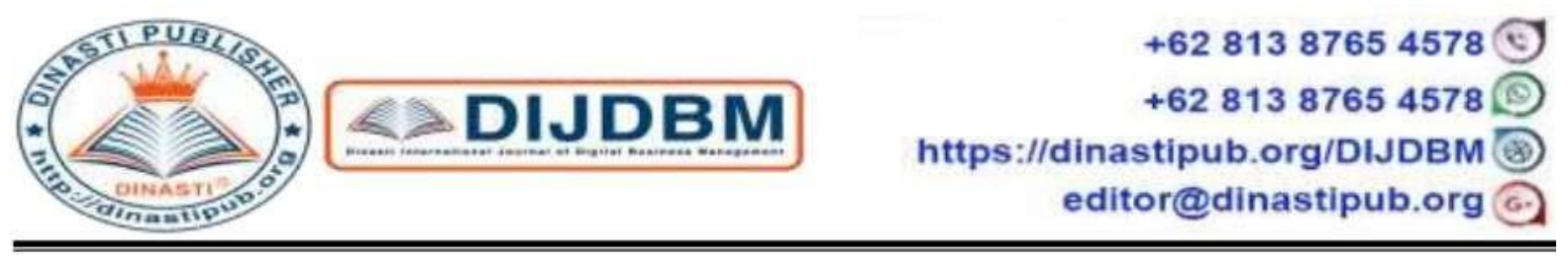

\title{
EFFECT OF GLOBAL MINDSET AND ENTREPRENEURIAL MOTIVATION TO ENTREPRENEURIAL SELF-EFFICACY AND IMPLICATION TO ENTREPRENEURIAL INTENTION
}

\author{
1) M. Havidz Aima, ${ }^{2)}$ Suta Achmad Wijaya, ${ }^{3)}$ Lenny Carawangsa, ${ }^{4)}$ Ma Ying \\ 1) 2) 3) Mercubuana University, Jakarta, Indonesia \\ 4) Wuhan University of Technology, Wuhan, China
}

\section{ARTICLE INFORMATION}

Received: 1 February 2020

Revised: 15 February 2020

Issued: 20 February 2020

\section{Corresponding Author:}

Havidz Aima

\section{E-mail:}

havidz.aima@yahoo.com a.h.sutawijaya@mercubuana.ac.id lenny.nawangsari@gmail.com

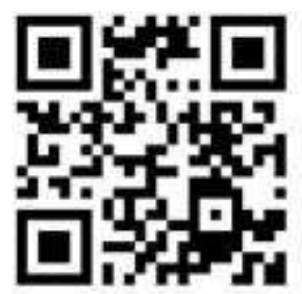

DOI:10.31933/DIJDBM
Abstract: The research method used a quantitative approach, which the sample of in this study were 100 Stdents of Faculty of Economics of Mercu Buana University (MBU), Jakarta, academic year 2019/2019 as the representative of the population of Faculty of Economics at the same year. Data collection techniques using interview and questionnaire. The questionnaire survey instrument was delivered to the respondents. Data were analyzed by using structural equation model (SEM) with the Smart PLS3.0 software program. This study reveals that the global mindset significantly influence to entrepreneur self-efficacy and to Entrepreneur Intention. Otherwise, entrepreneur motivation has no significant effect to entrepreneur selfefficacy and to entrepreneur intention. Self-Efficacy significantly mediate Globbal Mindset to Entreprepreneurial Intention, but it does not significantly mediate Entrepreneurial Motivation to Entrepreneurial Intention. Other finding, Global Mindset and Entrepreneurial Motivation are simultaneously and significantly influence Self-Efficacy; and three of proposed variable are simultaneuosly and significantly influence Entrepreneurial Intention. Refers to the research finding, the main factor to anyone to become as an Entrepreneur is mindset. Thus, one should have been involve with Entrepreneurship activity trough first hand experience from a young age

Keywords: Global Mindset, Entrepreneurial Moti-vation, Entrepreneurial Self-Efficacy, and Entrepreneurial Intention, 


\section{INTRODUCTION}

According to the records of the Ministry of Cooperatives and Small and Medium Enterprises (UKM), the number of entrepreneurs in Indonesia was increased from the previous one of only $1.67 \%$ to be-come $3.10 \%$ of the total (https://www.google.com/ search). However, this percentage is still lower with some neighboring countries, for example, Malaysia is more than $5 \%$, and Singapore is more than $7 \%$.

There are three supporting reason behind the job tendency of the Indonesian to be a sivil servant than to be an entrepreneur: (a) prestigious value, (b) Indonesian colonized by Ducth and Japan, and (c) Indonesian is lack of mindset regarding entrepreneur.

\section{LITERATURE REVIEW}

\section{Entrepreneur and Entrepreneurship}

Entrepreneurship has significant role in moving the economy of the nation, encourage job creation, in distribution of income improvement, and even improving of community life welfare. To develop an entrepreneurial mindset, such as Hisrich at.al; 2005, in Moira KostićBobanović and Mieta Bobanović, defines entrepreneurship as the process of creating something new with value by devoting the necessary time and effort, assuming with accompanying physic and social risk's.

Moreover, independence, according to the definition, it is clear that an entrepreneur has several important characteristics, such as innovative, creative, and calculated risk taking. The character of innovative creative is also emphasized in the definition of entrepreneur by Bolton and Thompson (2004:16). To engage in various entrepreneurial tasks repeatedly hence enhance their confidence in performing such tasks in the future (Shinnar et al., 2014). By so doing, entrepreneur develop their confidence and ability to perform and increase entrepreneurial self-efficacy (Shinnar et al., 2014).

Things can affect Entrepreneurial Intention namely: culture, education, experience, and expectation. Regarding, culture aspecs, it will vary from country to country. Similarly, in the same country the culture will also be different between different regions or provinces.

A study found that people who work for themselves have a four times greater chance of becoming millionaires than people who work for others(Scarborough 2008). To be a millionaire is certainly everyone's dream to realize this dream (Soetrisno 2010) someone must have hope, optimism, consistency, and integrity (Tracy), scientifically the saying about sowing confirms that "You sow a though and you reap a habit; you sow a habit and you reap a character; you sow a character and you reap a destiny" reveals that one's fate depends on his thoughts.

The mind is the factory of thought. Like land, buy processed, fertilized, planted seeds, irrigated and maintained, it will grow plants as desired; but instead it will grow weeds. Likewise positive thoughts are the main key tool for achieving success. According to(Clements 2001), five golden rules for having a positive attitude: being professional, having a vision, always being fit, being fair, and team oriented. Thus, mindset will affect various things. 
Entrepreneurship is an act of innovation that involves endowing existing resources with new wealth-producing capacity; the ability to perceive new opportunities; the ability to perceive new opportunities. This recognition and seizing of the opportunity will tend to "correct" the market and bring it back toward equilibrium Drucker (1985), Kirzner (1973).

Early of 1800, the French economist, J.B. Say, in Drucker (1993), said that "The entrepreneur, shifts economic resources out of an area of lower and into an area of higher productivity and greater yield." Nor, entrepreneurs, although they need capital as all economic as well most of noneconomic, but the difference is the essence of economic activity is the commitment of present resources to future expectations, which means, their concern to uncertainty and risks. The entrepreneur is not an employer, but can be, and often is, an employee or even someone who works alone and entirely by him/herself.

\section{Global Mindset}

Mindset, according to(Hendro 2013), means that, we must first be free to think and open the mind so that we do not limit ourselves to new things and new knowledge,. by following a visionary and positive concept. This is a sign that you are in the process of building a new paradigm to find inspiration by using a creative mindset.

On the other hand according to (Santoso 2014) many things were created twice, the first creation starts from the mind and the second creation is the realization of what is in the mind. One of the determinants of a person's quality of life is the mind, therefore to create a quality life and in accordance with what is expected, the initial step starts from the mindset. Moreover, according to (Khoo) a person's mind, behavior, abilities, and expertise are not determined by the number of brain cells they have.

The development of global mindset is a global issues now days, although for building a global mindset still are numerous as a big assignment internationally which means of developing the skills and knowledge needed by global leaders (Crowne, 2008; Gregerson, Morisson, \& Black, 1998, in Lovvorn, AI S; ChenJlun-Shiu, 2011.

To understand the concept of global mindset, Maznevski and Lane (2004: 172), argued that rather than seeing situations through an interdependence lens, a global mindset is the ability to develop and interpret criteria for personal and business performance that are independent from assumptions of a single country, culture, or context, and to implement criteria appropriately in different countries, culture, and context.

To be an entrepreneur is think differently while most of people conduct one-self the same with each other, seek refuge and avoid the risks, and want to be an employee. Entrepreneur is usually a person who exploits opportunities for the purpose of economic creation. Such definition over decade is, entrepreneur is a risk taker while exploiting opportunities (Van Praag 1999) (Knight, 1921; and Say, 1803); more explicitly as opportunity creator and innovation (Schumpeter, 1934).

Although business is look easiest to understand but the differentiation to an entrepreneur is in the way in which he think and react. This aspect of an entrepreneur is referring to the mindset. With the eagerness in different feel accepting the challenge, it's formed someone foundation of education of entrepreneurship. 
An entrepreneur strongly believes, their patience goes through the process it will be very useful to reach the set target through the market that was planned. An entrepreneur, he always "thing big" which is, pursuing his ideas and maximize his potentiality to additional expand segment's and ready with the environment restrict(Johnson 2013). For example, Hollywood has yet to tell the stories the famous female entrepreneur in the early 1990s; she is Madam C. J. Walker who turned her homemade recipes for hair and scalp care products into a business empire that made her the United States' first self-made black female millionaire(Malin and CarsrudAlan 2016).

\section{Entrepreneurial Motivation}

To motivate people it is necessary to know how motivation works. High Performance is achieved by high motivation for people who are prepared to take the opportunity with discretion effort. For people, a motive is a reason for doing something. Motivation is concern with the strength and direction of behavior and the factors that influence people to behave in certain ways.

\section{Entrepreneurial Self-Efficacy}

Bandura defined self-efficacy as task-specific consideration of perceived fitness to perform a particular activity. In the case of entrepreneurship, entrepreneurial self-efficacy may be comprised of deliberation of those tasks that relates to the intention and development of new ventures. Still by Bandura, contended that role model influence occurs primarily through mastery of experiences by repeatedly performance accomplishment, observation learning, and social persuasion that convincing task can be performed. Even though according to Zhao, Seibert, \& Hills result found that individuals choose to become entrepreneurs most directly because they are high in entrepreneurial. Self-efficacy, the beliefs that they can succeed in role, gender is not related to entrepreneurial self-efficacy but was directly related to entrepreneurial intentions.

\section{Entrepreneurial Intention}

Attitudes are believed to act as mediators for influences of personal background factors. The importance role of entrepreneurship is helping to achieve economic development, competitiveness, jobs creation, and national prosperity to a marked global interest into the development of business and entrepreneurship education, and that will lead to increase in social, economic and organizational development ;(Martinez 2010);(Singer 2015).

A critical role in the development of enterprising graduates by identifying and generating aptitudes or by helping to promote entrepreneurial behaviours and intent(Ferreira 2018). The creation of new enterprises is regarded as essential for the development of national economies(Fayolle 2016). Nowdays generally accepted that entrepreneurship can be taught and learned, and that it is not restricted to those who are born with certain skills, attributes or characteristics(Harris 2008);(Kuratko 2005). 


\section{Research Framework}

To know the impacts and or the correlations among variables are described as research framework/Schematic Model of relationship between variables in Figure 1 below.

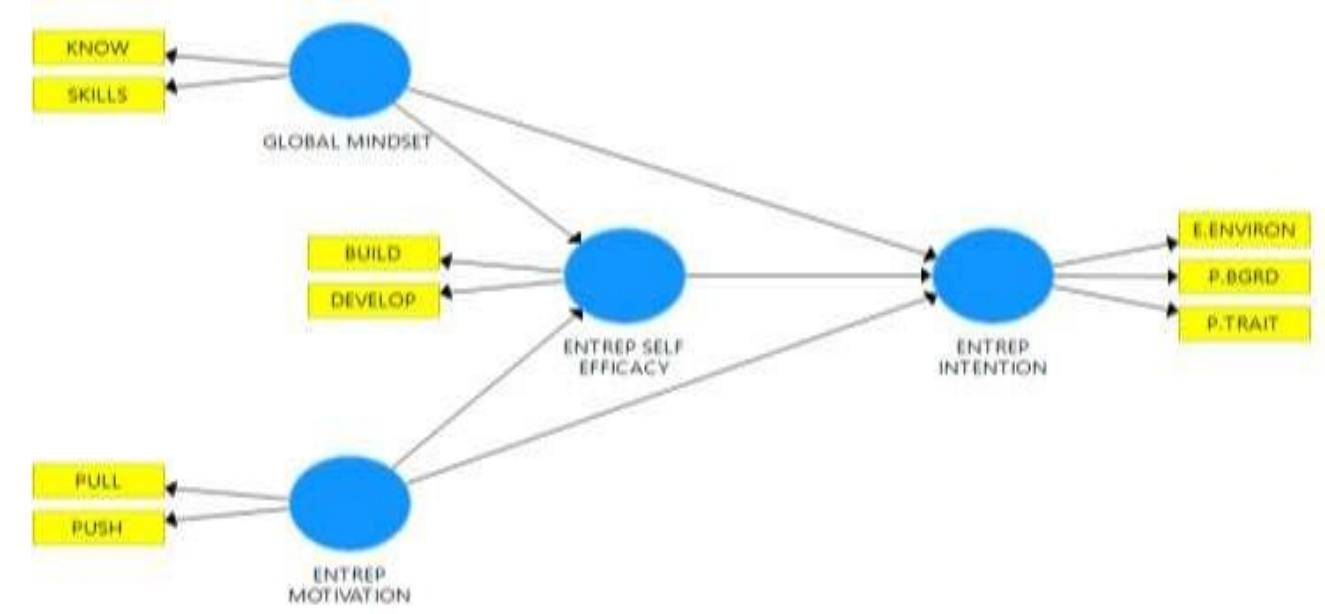

Figure 1:Schematic Model of relationship between variables

\section{Hypotheses}

1. Global Mindset and Entrepreneurial Votivation has a positive significant effet to SelfEfficacy and to Entrepreneurian Intention.

2. Self-Efficacy is a Mediating Variable on Global Mindset and Entrepreneurial Motivation to Entrepreneurial Intention.

\section{RESEARCH METHODS}

The type of research used is quantitative research using primary data in the form of surveys. This study was designed with the aim of being able to analyze, understand, and explain the influence of exogenous variables (Independent) on indogenous variables (dependent), as well as analyzing correlation matrices between variable dimensions.

The details of the variable are measured through dimension and indicator. The number of items is provided in Table 1. The independent variable (exogenous) that measured by bipolar scale; X1 (global mindset) and X2 (entrepreneur motivation), while the dependent variable (endogenous) are entrepreneur self-efficacy (Y1) as well as mediation variable and entrepreneurr intention (Y2).

Tabel 1 Operational Variable of the Study

\begin{tabular}{|l|l|l|l|c|}
\hline Variable & \multicolumn{1}{|c|}{ Dimension } & Indicator & Measurement & $\begin{array}{c}\text { Item's } \\
\text { number }\end{array}$ \\
\hline $\begin{array}{l}\text { Global } \\
\text { Mindset, } \\
\text { (X1) }\end{array}$ & $\begin{array}{l}\text { 1. Knowledge, } \\
\text { (X1.1) }\end{array}$ & $\begin{array}{l}\text { 1. Mastery of Tecnology } \\
\text { (X1.1.1) } \\
\text { 2. International socio-political } \\
\text { and economic perspective } \\
\text { (X1.1.2) } \\
\text { Chen, 2011) } \\
\text { 3. Understanding of cultural } \\
\text { issues (X1.1.3) }\end{array}$ & Bi polar scale & 1,2 \\
\hline
\end{tabular}




\begin{tabular}{|c|c|c|c|c|}
\hline & 2. Skills, (X12) & $\begin{array}{l}\text { 1. Acculturation (X12.1) } \\
\text { 2. Leadership for managing } \\
\text { diversity (X12.2) }\end{array}$ & Bi polar scale & $\begin{array}{c}7 \\
8,9\end{array}$ \\
\hline $\begin{array}{l}\text { Entrepreneu } \\
\text { rial } \\
\text { Motivation } \\
(\mathrm{X} 2) \\
\text { (Yimamu, } \\
\text { 2018) }\end{array}$ & $\begin{array}{l}\text { 1. Pull Factors } \\
\text { (X2.1) } \\
\text { 2. Push Factors } \\
\text { (X2.2) }\end{array}$ & $\begin{array}{l}\text { 1.Need for achievement } \\
\text { (X2.1.1) } \\
\text { 2.Need for independence and } \\
\text { financial freedom (X2.1.2) } \\
\text { 3.Persistent love for doing } \\
\text { something great (X2.1.3) } \\
\text { 1. (X2.2.1) } \\
\text { 2. (X2.2.2) } \\
\text { 3. (X2.2.3) }\end{array}$ & Bi polar scale & $\begin{array}{c}10,11 \\
\\
12,13 \\
14,15 \\
16,17 \\
18,19 \\
20,21\end{array}$ \\
\hline \multirow{2}{*}{$\begin{array}{l}\text { Entrepreneu } \\
\text { rial Self- } \\
\text { Efficacy, } \\
\text { (Y1) } \\
\text { (Kostic- } \\
\text { Bobanovic } \\
\text { and } \\
\text { Bobanovix, }\end{array}$} & $\begin{array}{l}\text { 1. Developing } \\
\text { New Product } \\
\text { and Market } \\
\text { Opportunity, } \\
\text { (Y1.1) }\end{array}$ & 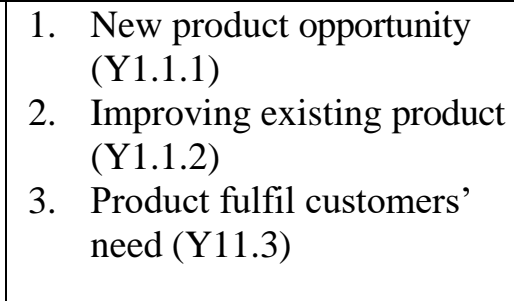 & Bi polar scale & $\begin{array}{l}22,23,24 \\
25,26,27\end{array}$ \\
\hline & $\begin{array}{l}\text { 2. Building and } \\
\text { Innovative } \\
\text { Environment, } \\
\text { (Y1.2) }\end{array}$ & $\begin{array}{ll}\text { 1. } & \text { Encourage people to } \\
\text { something new (Y1.2.1) } \\
\text { 2. Encourage people to take } \\
\text { initiatives (Y1.2.2) } \\
\text { 3. Encourage people to take } \\
\text { responsibility for their } \\
\text { ideas (Y1.2.3) }\end{array}$ & & $\begin{array}{c}31,32 \\
33 \\
34,35,36\end{array}$ \\
\hline \multirow{3}{*}{$\begin{array}{l}\text { Entrepreneu } \\
\text { rial } \\
\text { Intention } \\
\text { (Y2) } \\
\text { (Wang, } \\
\text { Zheng, } \\
\text { Zheng, and } \\
\text { Lin, 2018) }\end{array}$} & $\begin{array}{l}\text { 1.Personal } \\
\text { Background } \\
\text { (Y21) }\end{array}$ & $\begin{array}{l}\text { 1.Education (Y2.1.1)) } \\
\text { 2. Parent occupation (Y2.1.2) } \\
\text { 3. Growing-up area (Y2.1.3) }\end{array}$ & Bi polar scale & $\begin{array}{l}37 \\
38 \\
39\end{array}$ \\
\hline & $\begin{array}{l}\text { 2.Personality } \\
\text { Traits (Y22) }\end{array}$ & $\begin{array}{l}\text { 1. Need for self-actualization } \\
\text { (Y2.2.1) } \\
\text { 2. Risk taking (Y2.2.2) } \\
\text { 3. Recognition ability (Y2.2.3) } \\
\text { 4. Innovative ability (Y2.2.4) }\end{array}$ & Bi polar scale & $\begin{array}{l}40 \\
41 \\
42 \\
43\end{array}$ \\
\hline & $\begin{array}{l}3 . \quad \text { Entrepr } \\
\text { eneurial } \\
\text { Environment } \\
\text { (Y23) }\end{array}$ & $\begin{array}{l}\text { 1. Financial support (Y2.3.1) } \\
\text { 2. Entrepreneurship education } \\
\text { and training (Y2.3.2) } \\
\text { 3. Business environment } \\
\text { (Y2.3.3) }\end{array}$ & & $\begin{array}{l}44 \\
45 \\
46\end{array}$ \\
\hline
\end{tabular}

\section{Population And Sample}

Population in this studi is Bachelor student of Faculty of Economics of Mercu Buana University, Jakarta, Indonesia, academic year 2018/2019.

Purposive sampling was applied in this research, which student,s number are 100 students. It was refers to the availability of the respondent. 


\section{Method Analysis}

This research applied the analysis data techniques by utilizing SmartPLS version 3.2.7 and being run by computer. Partial Least Square (PLS) is a structural equation model (SEM) analysis by using its variant simultaneously to test measurement model as well as structural model. Through PLS approach, it assumes that all the variances could be used to explain the data analysis technique in the research and it is divided into two, such as:

1. Descriptive statistic analysis is an empirical analysis that describe any information that obtained to figure or explain certain cases (who/what, when, where, how, and how many) and its is collected in the research (Supranto:2012). Those data are from the respondents' answers for the items on the questionnaire. Researchers will process the acquired data by separating it into categories, do the tabulation and explain afterwards.

2. Inferential statistic analysis is a statistic technique that will be used to analyze data sample and the results will be used for the population (Sugiyono:2009). Along with the hypotheses, thus the inferential statistic data analysis in this research will be using SmartPLS software (Partial Least Square) for its outer model, inner model and hypotheses measurements.

\section{RESULTS AND DISCUSSIONS}

Convergent validity evaluation from the investigation of individual item reliability could be measured from the value of standardized loading factor. Standardized loading factor assesses the correlation between each item of indicator with its construct. Loading factor value that applied in this research is $>0.5$, hence if the loading factor value is $<0.5$ on the calculation model result (outer model) it will be excluded from the model, and the results is all Indicator namely Global Mindset, Entrepreneurial Motivation, Entrepreneurial SelfEfficacy, and Entrepreneurial Intention variable indicates loading factor value for $>0.50$. This result revealed that all indicator are valid and will be used in this research or are not being excluded from the model.

Convergent validity evaluation from the investigation of Average Variance Extracted (AVE) describe the amount of variant or variant of manifest variable that could be possessed by its latent construct. The greater variant of manifest variable that could be possessed by its latent construct, the greater representation of manifest variable to the latent construct. Convergent validity evaluation from the investigation of Average Variance Extracted (AVE) could be measured from its AVE value based on the data tabulation with SmartPLS version 3.2.7.

Table 2: The Mean Value of Average Variance Extracted (AVE) for Each Variable

\begin{tabular}{lc}
\hline \multicolumn{1}{c}{ Variable } & Nilai Average Variance Extracted (AVE) \\
\hline Global Mindset & 0.873 \\
Entrepreneur Motivation & 0.833 \\
Entrepreneur Self-Efficacy & 0.881 \\
Entrepreneur Intention & 0.774 \\
\hline
\end{tabular}


Based on the table above, it reveals that all the variables have $>0.50$ of AVE value. Convergent validity evaluation from the investigation of internal consistency reliability could be measured from the value of Cronbach's Coefficient Alpha and Composite Reliability (CR) that provided on the table below. The table provided is a result of SmartPLS version 3.2.7.

Table 3: Cronbach's Coefficient Alpha dan Composite Reliability (CR) Value

\begin{tabular}{lcc}
\hline Variable & Cronbach's Alpha & Composite Reliability \\
\hline Global Mindset & 0.854 & 0.932 \\
Entrepreneur Motivation & 0.799 & 0.909 \\
Entrepreneur Self-Efficacy & 0.865 & 0.937 \\
Entrepreneur Intention & 0.854 & 0.911 \\
\hline
\end{tabular}

Based on the table 3, it reveals all value of Cronbach's Coefficient Alpha for Global Mindset, Entrepreneur Motivation, Entrepreneur Self-Efficacy, and Entrepreneur Intention on the Indonesian studies objectives are more than 0.6 or even close to 1 . In addition, its Composite Reliability (CR) value of every variables on the Indonesian students have achieved its threshold that are above 0.6. Hence all the variables in this research are reliable.

Table 4. Validity test (Cross loadings)

\begin{tabular}{llccc}
\hline & $\begin{array}{c}\text { G. Mindset } \\
(\mathbf{X 1})\end{array}$ & $\begin{array}{c}\text { E. Motivasi } \\
(\mathbf{X})\end{array}$ & $\begin{array}{c}\text { E. S-Efficacy } \\
(\text { Y1 })\end{array}$ & $\begin{array}{c}\text { E. Intention } \\
(\text { Y2 })\end{array}$ \\
\hline $\mathrm{X} 11$ & 0.935 & 0.489 & 0.708 & 0.617 \\
$\mathrm{X} 12$ & 0.933 & 0.585 & 0.701 & 0.684 \\
$\mathrm{X} 21$ & 0.496 & 0.906 & 0.463 & 0.366 \\
$\mathrm{X} 22$ & 0.551 & 0.919 & 0.498 & 0.496 \\
Y11 & 0.675 & 0.464 & 0.935 & 0.658 \\
Y12 & 0.740 & 0.524 & 0.942 & 0.669 \\
Y21 & 0.564 & 0.386 & 0.596 & 0.861 \\
Y22 & 0.678 & 0.522 & 0.656 & 0.904 \\
Y23 & 0.592 & 0.338 & 0.613 & 0.874 \\
\hline
\end{tabular}

It can be concluded from Table 4 that the study has fulfilled the discriminant validity test criteria of cross loadings. All indicators on the constrict of global mindset variable have a cross loading value that is greater than the value of other constructs loading that are entrepreneur motivation, entrepreneur self-efficacy, and entrepreneur intention. All indicators on the construct of entrepreneur motivation variable have a cross loading value that are greater than the value of other cross loading constructs namely global mindset, entrepreneurial self-efficacy, and entrepreneurial intention. Moreover, every indicators on the construct of entrepreneurial self-efficacy variable have a cross loading value that are greater than the value of the other construct, namely global mindset, entrepreneurial motivation, and entrepreneurial intention. Lastly, all indicators on the construct of entrepreneurial intention 
variable have a greater cross loading values, namely entrepreneur motivation, entrepreneurial self-efficacy, and global mindset.

\section{Demographic findings of the study}

The demographic findings of the study is written in Table 4. It can be seen from the table that the number of the female students are higher than the male students. The most important finding of the study the parents job of the students are mostly as a private employees (44\%). It was found that mostly the Indonesian students desired job is to be a business owner, in fact, the occupation tendency of the people reside is to be a private employee, especially to be a sivil servant.

Table 5 Demographic Findings of the Study

\begin{tabular}{|c|c|c|}
\hline Description & Frequencies & Percentages (\%) \\
\hline \multicolumn{3}{|l|}{ Gender } \\
\hline Male & 42 & 42.0 \\
\hline Female & 58 & 58.0 \\
\hline \multicolumn{3}{|l|}{ Parents Job } \\
\hline Civil Servants & 32 & 32.0 \\
\hline Private Employee & 44 & 44.0 \\
\hline Business Owner & 24 & 24.0 \\
\hline \multicolumn{3}{|l|}{ Desired Job } \\
\hline Civil Servants & 21 & 21.0 \\
\hline Private Employee & 42 & 42.0 \\
\hline Business Owner & 36 & 36.0 \\
\hline
\end{tabular}

\section{Statistical Inference Findings}

For the structural model evaluation (inner model) or hypothesis test in this research is proceed on several steps, such as evaluating path coefficient value, based on SmartPLS version 3.2.7 calculation using bootstrapping and it reveals the result for path coefficient and T-Value that explain the relationship between construct/variable as shown in Figure 2 and Figure 3.

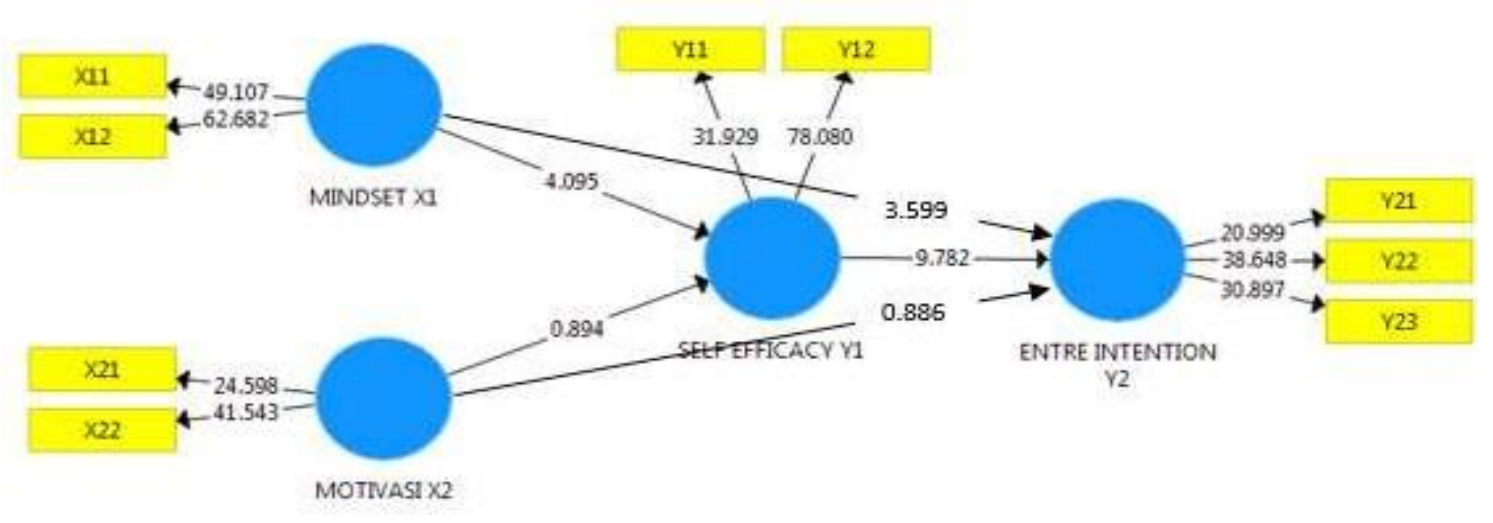

Figure 2. T-Value 


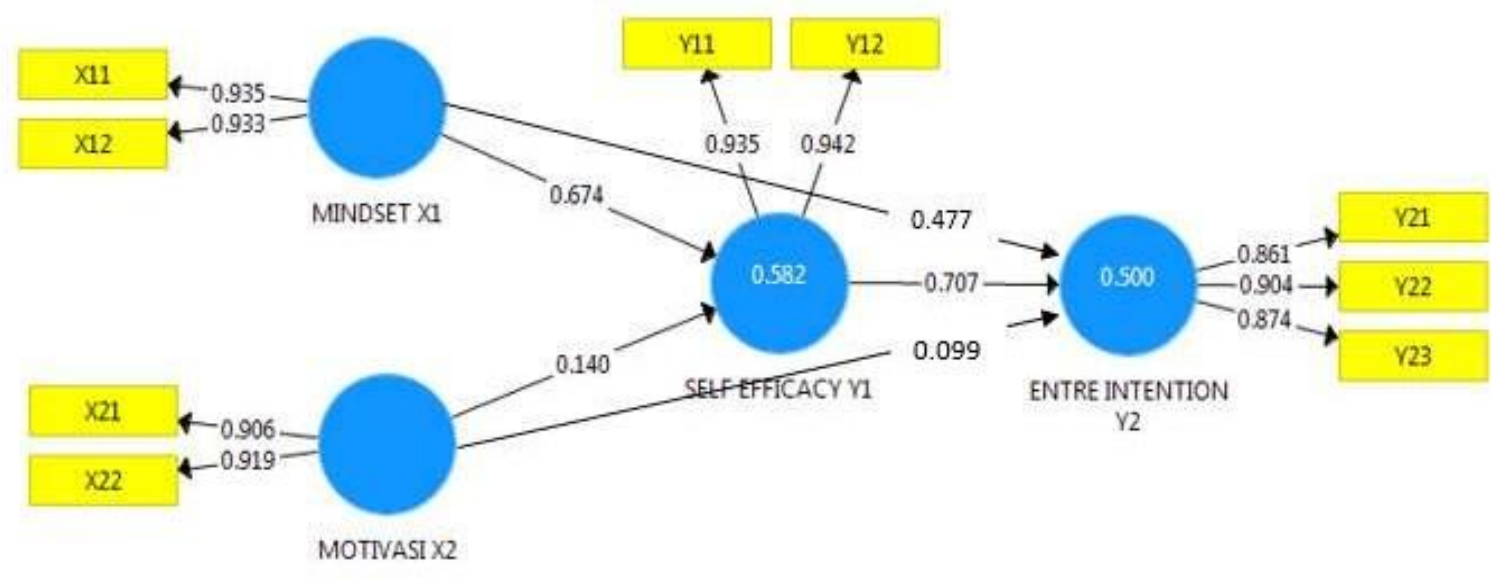

Figure 3. Path Coefficient

Global mindset (X1) has positive significant influence to entrepreneur self-efficacy (Y1) and to Entrepreneur Intention (Y2). But, entrepreneurial motivation (X2) has no significant effect to entrepreneur self-efficacy (Y1) and to entrepreneur intention (Y2). The result analysis of the study in more detail can be seen in Table 5.

Table 5: Path Coefficient Test Result

\begin{tabular}{lccc}
\hline & $\begin{array}{c}\text { Original Sample } \\
(\mathbf{O})\end{array}$ & T Statistik (O/STDEV) & P Values \\
\hline $\begin{array}{l}\text { Gobal Mindset (x1) -> } \\
\text { Entrepreneur Self-Efficacy } \\
\text { (y1) }\end{array}$ & 0.674 & 4.095 & 0.000 \\
$\begin{array}{l}\text { Global Mindset (x1) -> } \\
\text { Entrepreneur Intention (y2) }\end{array}$ & 0.477 & 3.599 & \\
$\begin{array}{l}\text { Entrepreneur Motivation } \\
\text { (x2) -> Entrepreneur Self- }\end{array}$ & 0.140 & & 0.000 \\
$\begin{array}{l}\text { Efficacy (y1) } \\
\begin{array}{l}\text { Entrepreneur Motivation } \\
\text { (x2) -> Entrepreneur }\end{array}\end{array}$ & 0.099 & 0.894 & 0.372 \\
$\begin{array}{l}\text { Intention (y2) } \\
\begin{array}{l}\text { Entrepreneur Self-Efficacy } \\
\text { (y1) -> Entrepreneur }\end{array}\end{array}$ & 0.707 & 0.886 & \\
Intention (y2) & & & 0.376 \\
\hline
\end{tabular}

Analysis on the Mediation Variable of the study

1. Entrepreneur self-efficacy as mediating variable to global mindset and entrepreneur intention

$(0.674 \times 0.707)=0.476>0.228=(0.477)^{2}$

It is proven that entrepreneur self efficacy as mediating variable to global mindset and entrepreneur intention, both on chinese and Indonesian students. 
2. Entrepreneur self-efficacy as mediating variable to entrepreneur motivation and entrepreneur intention

$(0.140 \times 0.707)=0.099>0.01=(0.099)^{2}$

It is proven that entrepreneur self efficacy as mediating variable to entrepreneur motivation and entrepreneur intention, both on chinese and Indonesian students.

The result and testing of the mediating variable in the study is shown in figure 4 .

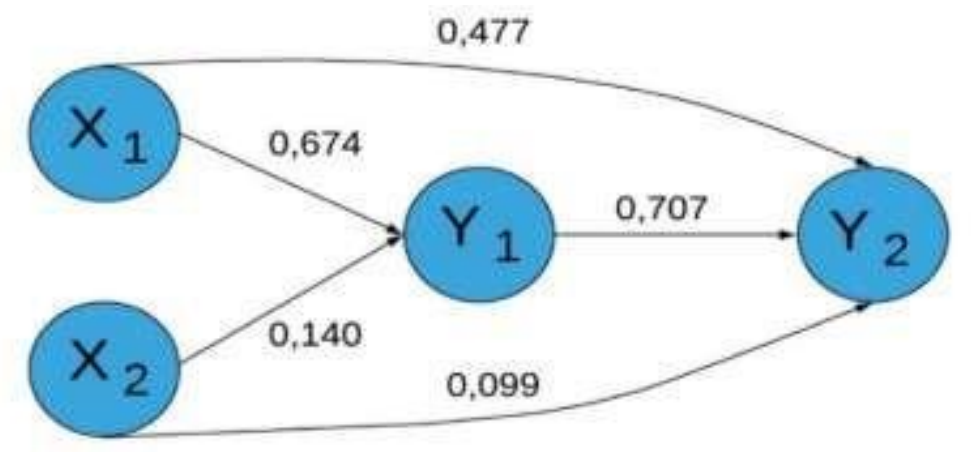

Figure 4. The result and testing of the mediating variable in the study

\section{Interdimensional Correlation Matrix}

Interdimension correlation matrix is shown in Table 6.

Table 6. Interdimensional correlational matrix

\begin{tabular}{|l|l|c|c|c|c|c|}
\hline & & \multicolumn{2}{|c|}{$\begin{array}{c}\text { Entrepreneur Self- } \\
\text { efficacy (Y1) }\end{array}$} & \multicolumn{2}{c|}{ Entreprenur Intention (Y2) } \\
\hline Variables & Dimensions & Y11 & Y12 & Y21 & Y22 & Y23 \\
\hline $\begin{array}{l}\text { Entrepreneur Mindset } \\
\text { (X1) }\end{array}$ & $\mathrm{X} 11$ & 0.648 & 0.681 & 0.509 & 0.585 & 0.531 \\
\cline { 2 - 7 } & $\mathrm{X} 12$ & 0.612 & 0.701 & 0.544 & 0.683 & 0.574 \\
\hline $\begin{array}{l}\text { Entrepreneur Motivation } \\
(\mathrm{X} 2)\end{array}$ & $\mathrm{X} 21$ & 0.401 & 0.467 & 0.263 & 0.418 & 0.276 \\
\cline { 2 - 8 } & $\mathrm{X} 22$ & 0.445 & 0.488 & 0.435 & 0.530 & 0.338 \\
\hline $\begin{array}{l}\text { Entrepreneur Self- } \\
\text { efficacy (Y1) }\end{array}$ & $\mathrm{Y} 11$ & & & 0.572 & 0.621 & 0.544 \\
\cline { 2 - 8 } & $\mathrm{Y} 12$ & & & 0.548 & 0.612 & 0.605 \\
\hline
\end{tabular}

Remarks Table 6:

: Knowledge

: Skills

: Pull Factors

: Push Factors

Y1.1 : Developing New Product and Market Opportunity

Y1.2 : Building and Innovative Environment

Y2.1 : Personal Background

Y2.2 : Personal Traits

Y2.3 : Entrepreneurial Environment 


\section{CONCLUSION AND SUGGESTION}

\section{Conclusion}

1. Global mindset has positive significant influence to entrepreneur self-efficacy and to Entrepreneur Intention.

2. Entrepreneur motivation has no significant effect to entrepreneur self-efficacy and to entrepreneur intention.

3. The study indicates that entrepreneur self efficacy as mediating variable to global mindset and entrepreneur intention.

\section{Recommendation}

1. Between global mindset variable and entrepreneur motivation variable, global mindset variable is significantly influence entrepreneur self-efficacy and entrepreneur intention. Thus, to increase entrepreneurial intention is to improve mindset regarding entrepreneurship. Thus, any one who wish to be an entrepreneur should prepare themselves through observing and experiencing anything related to entrepreneurship activities.

2. Refers to the table 6 (Interdimensional Correlation Matrix), to increase the entrepreneur intention the best way are: (1) directly improve the skills and builds innovative environment; (2) indirectly improve the development of new product and market opportunity and increase the personal traits.

\section{REFERENCE}

Bolton. B. and Thompson. J. (2004). Entrepreneurs: Talent. Temperament. Technique. Norfolk: Biddles, 16, 12-28.

Crowne. KA. et.all. ( 2008); Developing a Global Mindset: The relationship between an international assignment and cultural intelegence. (2008). Journal of Business and Social Science. Academy of Management Journal, 44 (30): 533-545

Drucker. P., F. (1985). Innovation and Entrepreneurship. Harper, New York, London, Toronto, Sydney.

H Van Praag (1999). Running Enhences Neurogenesis, and Learning, and long-term potentiation in mice. PublMed. US National Library of Medecine National Institute of Health

Hendro., (2013).

Hisrich. R.D. Peters. M.P.. and Shepherd. D.A. (2005). Entrepreneurship. Boston: McGrawHill, 1-21

Hull. C. (1951). Drive Reduction Theory of Learning. Journal of the Experimental Analysis of Behavior 51(2) · March 1989 DOI: 10.1901/jeab.1989.51-277 · Source: PubMed Central

Hornaday (1982).Entrepreurship and Management: Differing but Complementary Processes. Montreal University Business School. Canada.

https://www. soas.ac.uk/ cedep-demos/000_P501_USD_K3736-Demo/unit1/page_12. Htm 
https://www.fimela.com/lifestyle-relationship/read/2344643/9-negara-dengan-jumlahpengusaha-terbanyak-di-dunia

https://www.google.com/search

Kirzner, I., M. (1973). Competition and Entrepreneurship: University of Illinois at UrbanaChampaign's Academy for Entrepreneurial Leadership Historical Research Reference in Entrepreneurship. New York University.

Knight (1921, 1971) From Entrepreneurship to Entreprenology. (1998). Journal of Enterprising Culture, vol. 6, no 1 (March 1998) : 1-23. Published in Kunkel, Scott W. Ed.0 (1997) Journal of Best Papers.

Lovvorn., Al S., Jiun-Shiu Chen. (2011). Developing a Global Mindset: The Relationship between an International Assignment and Cultural Intelligence. International Journal of Business and Social Science. Vol. 2 No. 9 [Special Issue - May 2011].

Maznevski. ML., Lane. HW. (2004). Globalization: Hercules meets Buddha. The Blackwell handbook.

M.J.Dollinger (1995). Entrepreneurship: Strategies and Resources. Business Administration and Management. Austen Press.

Michael A. Hitt., R. Duane I. S., S. Michael Camp. Donald. L. (2002. Strategic Entrepreneurship: Creating a New Mindset. Willey-Blackwell. ISBN 13:9780631234104

Rhinesmith, S., H. (1995). Open the door to a global mindset.

Rita Remeikiene, Grazina Startiene Daiva, Dumciuviene. 2013. Explaining Entrepreneurial Intention Of University Students: The Role Of Entrepreneurial Education.

Santoso., (2014).

Scarborough, \& Zimmerer. (2008). Psychology at work in Asia: Proceeds of the 3rd and 4th Asian Psychological. p. 222

https://www.sciencedirect.com/science/article/abs/pii/S1472811714000512, https://doi.org/10.1016/j.ijme.2014.09.005

Shinnar,R., Dan. K-H, Benjamin C.P (...) Self-efficacy, Entrepreneurial Intentions, and Gender: Assessing The Impact of Entrepreneurship Education Longitudinally.

Shinnar,R., Pruett,M., and Toney,B.,(2009),'Entrepreneurship Education: Attitudes Across Campus", Journal of Education for Business, Heldref Publications

Soetrisno. B. (2010). Pengaruh Partisipasi, Motivasi dan Pelimpahan Wewenang dalam Penyusunan Anggran Terhadap Kinerja Manajerial (Studi Empiris Pada Dinas Daerah dan Lembaga Teknis Daerah di Kabupaten Rembang). Tesis. Universitas Diponegoro. Semarang.

Wang, C.-H., Zheng, X., Zheng. L., \& Lin,-H. (2018) the Application of FAHP on Influencing Factors Evaluation Entrepreneurial Intention of College Students. The 2018 International Conference of Organizational Innovation (pp. 1555-1564). Knowledge E. 